YEARBOOK

of ANTITRUST

and REGULATORY

STUDIES

www.yars.wz.uw.edu.pl
Peer-reviewed scientific periodical, focusing on legal and economic issues of antitrust and regulation. Creative Commons Attribution-No Derivative Works 3.0 Poland License.

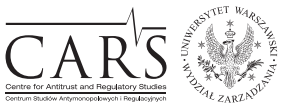

Centre for Antitrust and Regulatory Studies, University of Warsaw, Faculty of Management www.cars.wZ.uw.edu.pl

\title{
Private Enforcement and Opt-out System Risks, Rewards and Legal Safeguards
}

\author{
by
}

Maria Elisabete Ramos*

\section{CONTENTS}

I. Introduction

II. The private enforcement of competition law and the critical role of collective redress

A. Public enforcement and the suboptimal level of fines

B. Rational apathy and the under-enforcement of the consumer right to seek compensation for competition law infringements

III. Factors which ground the recommendation's hostility to the opt-out models

A. The White Paper's suggestion on the opt-in model

B. The Recommendation on Collective Redress and the rejection of the opt-out model

C. Assessing the Recommendation on Collective Redress proposals

D. 'A New Deal for Consumers' and the representative action

IV. Challenging the European Commission - the spread of opt-out models in Europe

A. The opt-out model makes part of the European legal experience

B. The opt-out model - advantages, incentives and risks

V. Rewards and safeguards of the Portuguese opt-out collective redress action

A. Competition law infringements and compensation of the injured consumers

B. The Portuguese opt-out model - rewards and risks

* Assistant Professor, Faculty of Economics of Coimbra. CeBER and Faculty of Economics, University of Coimbra; e-mail: mgramos@fe.uc.pt. Postal address: Faculdade de Economia da Universidade de Coimbra, Av. da Dias da Silva, 165, 3004-512 Coimbra. Article received: 11 October 2019; accepted: 11 Novemeber 2018. 

C. Compensation distribution and claimant's representative reward - new approaches
D. Funding the litigation costs - are new financial incentives needed?
VI. Conclusions

\begin{abstract}
The EU Antitrust Damages Actions Directive does not include provisions for collective redress. Each EU member state is free to provide national regulation on this matter. The Portuguese legal system provided regulation on actio popularis since 1995. The 'rational apathy' of individual consumers may lead to non-reparation of damage and be of significant benefit for the company that is in breach of the law. The opt-out models solve the crucial economic problem caused by a large number of consumers or clients who have suffered a small loss because of competition law infringements. Under those circumstances, it is rational to be apathetic, because it can be foreseen that the cost of filing for compensatory damages will exceed the recovery obtained from the defendant. Such rational apathy of the parties injured by competition law infringements favours the wrongfully acting companies by not extracting their illegal gains from them. By not requiring the active consent of each of the claimants, the opt-out model is able to override rational apathy of consumers.
\end{abstract}

\title{
Résumé
}

La Directive 2014/104/UE du Parlement Européen et du Conseil du 26 Novembre 2014 relative à certaines règles régissant les actions en dommages et intérêts en droit national pour les infractions aux dispositions du droit de la concurrence des États membres et de l'Union européenne n'offre pas des normes sur l'action collective. Chaque État-membre est libre d'adopter ses normes sur ce sujet. Lordre juridique portugais prévoit des normes sur l'actio popularis, depuis 1995. Lapathie rationnelle de chaque consommateur peut déclencher la non réparation des dommages causés par l'infraction des normes de concurrence. Cet effet signifie un bénéfice pour les entreprises qui violent le droit de la concurrence.

Le system opt-out donne la solution pour le problème causé pour des nombreux consommateurs qui souffrent des modestes dommages causés par des violations du droit de la concurrence. En ces situations, il est rationnel ne pas réagir, parce que les couts sont supérieurs aux bénéfices. Cette apathie rationnelle favorise les entreprises qui violent le droit de la concurrence. Le system opt-out est capable de surmonter les effets de l'apathie rationnel.

Key words: competition law; private enforcement; collective redress; opt-out system.

JEL: K15, K21, L49 


\section{Introduction}

Competition law deals with consumer welfare. European Union competition regulations aim to promote efficiency and consumer welfare, which is universally referred to as a leading benchmark, the protection of market structure and economic freedom, and market integration (Buxbaum, 2005, p. 475).

Notwithstanding the 'increasing "economisation" of antitrust enforcement' (Ezrachi, 2017, p. 49-75) of competition law, many differences remain across EU countries. Competition law is not an island in a given legal system; it is shaped by legal tradition, the judiciary, and social and political inputs. Many factors, including historical ones, influence the competition law system. Additionally, competition law 'in action' (Pound, 1910, p. 12) depends on the activity of many players, like enterprises, regulators, the judiciary, economic and legal experts, lawyers.

We must be aware of the role played by the judiciary. In fact, the capacity of the judiciary to properly assess and digest complex and evolving theories when considering antitrust cases is disputed (Posner, 2001, p. 925). 'While some jurisdictions benefit from experienced and dedicated competition courts, others may not' (Ezrachi, 2017, p. 63). The disparity between the court's capacity and economic complexity increases the likelihood for mistakes and error costs' (Baye \& Wright, 2011, p. 1).

Given that economic grounds, political, social and historical factors shape competition law, this article addresses the collective redress opt-out system, which is an important legal mechanism to grant compensation to consumers harmed by competition law infringement. This paper discusses the opt-out model's risks and advantages, assessing the factors which can trigger litigation abuse, and the safeguards which may mitigate such an undesirable outcome. In fact, some risks and rewards connected to the opt-out model are driven by specific social and cultural factors.

The opt-out model has become part of the European legal experience since some EU Member States adopted it. However, each of these Member States shapes its own regulations on the opt-out model differently, regardless of the European Commission Recommendation on the opt-in model. ${ }^{1}$

1 Commission Recommendation of 11 June 2013 on common principles for injunctive and compensatory collective redress mechanisms in the Member States concerning violations of rights granted under Union Law (2013/396/EU). 
The Directive on private enforcement ${ }^{2}$ does not require Member States to introduce class actions or other types of collective redress. Nonetheless, the national Directive's transposition processes have deepened the debate on the types of collective redress and on the pros and cons of each model (opt-in and opt-out).

The main questions discussed in this article are: $a$ ) In the context of private competition law enforcement, what is the role of collective redress? $b$ ) Which factors, including financial incentives, are grounds for the Recommendation's hostility towards the opt-out model? c) Does the European experience follow the European Commission or challenges the European Commission Recommendation? d) Which are the rewards and safeguards adopted by the Portuguese opt-out collective redress action?

The Portuguese legal system adopts an opt-out collective redress model, which can be filed by consumers who seek to be compensated for loss or damage caused by competition law infringements. So, the Portuguese legal experience is relevant to the consumer compensation topic, given it does not follow the European Commission Recommendation on the opt-in model. It is important to understand whether the Portuguese collective redress system incorporates an accurate balance between rewards and safeguards, or whether it can lead to litigation abuse.

\section{The private enforcement of competition law and the critical role of collective redress}

\section{A. Public enforcement and the suboptimal level of fines}

Competition has some special features. In fact, competition resembles a public commodity in that it has benefits for everybody because it brings lower prices, a wider choice, greater efficiency, and more products and services that meet consumers' needs. Rivalry among enterprises leads to the elimination of less efficient firms and businesses. This is the expected outcome of the competitive market (Ramos, 2016, 28).

However, there is a market failure that must be addressed by regulation - namely when market forces themselves cannot ensure compliance with competition rules. In the European Union, public enforcement by public

2 Directive 2014/104/EU of the European Parliament and of the Council of 26 November 2014 on certain rules governing actions for damages under national law for infringements of the competition law provisions of the Member States and of the European Union. http://www. concorrencia.pt/vPT/Noticias_Eventos/Comunicados/Paginas/Comunicado_AdC_200720.aspx. The Court of Appeal (Lisbon) slightly reduced the fines. 
authorities ensures respect for competition law, but the authorities do not have the competences to seek full compensation for consumers affected by competition infringements.

It is disputed whether the fine level is optimal or suboptimal for cartel deterrence in the European Market. According to Smuda, 'median overcharge rates are found to be 20.70 percent and 18.37 percent of the selling price and the average cartel duration is 8.35 years' (Smuda, 2014, p. 63). Smuda concludes that 'empirical evidence reveals that from an ex-post perspective the currently existing fine level of the EU Guidelines is insufficient for optimal cartel deterrence' Smuda, 2014, p. 63). Notaro suggests that in the case of the pasta cartel in Italy, the 'fines levied by the AGCM [The Italian Authority for Competition Law] in this particular case were below "optimal" levels' (Notaro, 2014, p. 87).

In the so-called 'salt cartel', the Autoridade da Concorrência estimated that, between 1998 and 2004, this cartel negatively impacted consumers, industry and competitors in the amount of 5.6 million euros. ${ }^{3}$ In this case, the Autoridade da Concorrência fined the cartelists in the amount of 910728 euros.

One may wonder whether a breach of the law (including competition law) is acceptable when such infringement is efficient for the wrongdoer. Some literature suggests the admissibility of an efficient breach of the law. Bainbridge wonders: 'Individuals routinely make cost-benefit-analysis before deciding to comply with some malum prohibitum law, such as when deciding to violate the speed limit. Is it self-evident that directors of a corporation should be barred from engaging in similar cost-benefit analysis?' (Bainbridge, 2002, p. 272-273). According to Pepper, 'The malum in se/malum prohibitum distinction appears, in older garb, to formulate the difference between law as a true prohibition (that is, the identification of conduct not to be tolerated) and law as cost (that is, the identification of conduct not to be penalized in some fashion, but which the citizen is still free to choose to do' (Pepper, 1995, p. 1577).

The 'law as a cost' perspective is generally rejected in the civil law legal systems (Fleischer, 2005, p. 147), yet, a corporation's directors strive for the best performance, the most efficient decision, in a strategic approach. Companies and enterprises take decisions on a cost-benefit basis. If, in the case of a competition law infringement, the cost of the fine is lower than the cartel's profits, there is an economic incentive to be a cartelist. This undesirable effect (at the end of the day, the cartelists benefit from being in the cartel) may occur if competition law enforcement is unable to extract the illegal benefits arising from the cartel.

3 http://www.concorrencia.pt/vPT/Noticias_Eventos/Comunicados/Paginas/Comunicado_ AdC_200720.aspx. The Court of Appeal (Lisbon) slightly reduced the fines. 
There is a gap between the cartel's negative impact and the effectiveness of the fines (Loureiro, 2017). In fact, economics literature suggests that the fines levied by the national authorities do not reach the 'optimal levels'. These conclusions may imply that the public enforcement of competition law, although necessary, is not enough to confer market efficiency. In fact, the fine is unable to extract all the illegal advantages arising from the cartel.

Compensating the consumers affected by the competition infringements is beyond the scope of public enforcement. There is a legal specialization, meaning that national authorities enforce competition law by imposing fines; meanwhile consumers and competitors seek compensation for the damage caused by competition law infringements ${ }^{4}$. Such specialization gives an opportunity for the complementary role of private enforcement.

The $10 \%$ legal ceiling does not apply to private compensation of damages. Consequently, private enforcement by seeking full compensation for loss may contribute, albeit complementarily, to the efficiency of the market and the efficient allocation of resources. Private enforcers are driven by the rewards they can get from the wrongdoers. The effectiveness of private enforcement depends on suitable rewards (especially financial rewards) given to private enforcers.

\section{B. Rational apathy and the under-enforcement of the consumer right to seek compensation for competition law infringements}

The ECJ's Crehan and Manfredi rulings asserted the right of each consumer to seek full compensation for the loss caused by a competition infringement. ${ }^{5}$ Despite legal and judicial recognition, the right to full compensation for loss caused by competition infringements faces an economic obstacle. The ordinary consumer who suffers damage when a cartel pushes up the price of the bread by 1 EURO has no economic incentive to bring the cartelists [before the courts or] to justice. Even though the claimant will be successful, legal costs are higher

4 According Rajabiun, 2012, p. 187, 'Long-term data on case filings, administrative resources, and judicial outcomes from the United States reveal that mixed regimes allow for the specialization of tasks between public and private enforcers: competition authorities focus on the regulation of dominance, while private litigants tend to identify collusion in contractual relations'.

${ }^{5}$ Kirst \& Van den Bergh, 2016, p. 1, identify the conflict 'between optimal leniency incentives and compensation for all victims". To solve this conflict, the authors suggest that "cooperating undertakings that have received immunity or reduction from fines would be granted the same protection against damages liability. Following this alternative solution, the non-cooperating members of the cartel would then have to compensate the victims for the harm caused by the cartel.' 
than any restitution they might receive from the cartelists. If the damage is relatively small from the economic point of view, the injured consumer tends to be apathetic and absorbs the damage - this is rational behaviour, in other words, this is the rational choice from an economic point of view. 'Consumers with dispersed interests and low individual stakes need special protection in market transactions, in political process and in adjudication' (Maciejewski, 2015, p. 7).

However, consumer apathy is not a desirable outcome from the macroeconomic perspective. ${ }^{6}$ This apathy benefits the cartelists, because they keep the illegal economic rewards accruing from the cartel and the injured consumer gets no remedy. ${ }^{7}$ The loss of 1 EURO per item means millions of euros if it is multiplied by millions of injured consumers (Mateus, 2006, p. 1079). If we consider the loss suffered by society as a whole, we realize how important it is to create legal mechanisms that can override the consumer's rational apathy. In fact, consumer apathy precludes the complete recovery of damages, jeopardizes the deterrent effect and does not promote market efficiency. 'Ideally, for consumers and for businesses, when a consumer suffers damage the redress should be available fully and timely and at minimal costs. This allows restoring the efficient allocation of resources and achieving other social goals such as justice and equal treatment and levelling the playing field between the defaulting enterprise and its competitors' (Maciejewski, 2015, p. 7).

Collective redress by allowing the aggregation of several individual claims in a single action solves the economic problem faced by consumers whose

${ }^{6}$ In fact, Laitenberger \& Smuda, 2015, p. 955, estimate the damage suffered by German consumers due to a detergent cartel active between 2002 and 2005 in eight European countries. Applying before-and-after and difference-in-differences estimations they found average overcharges between 6.7 percent and 6.9 percent and an overall consumer damage of about 13.2 million euros over the period from July 2004 until March 2005. Under the assumption that the cartel-induced share on turnover is representative for the entire cartel period and for all affected markets, the overall consumer damage would even sum up to about 315 million euros'. These authors add that the 'results further suggest that the retailers reacted to the price increases of the cartel firms via price increases for their own detergent products, resulting in significant umbrella effects'. They 'quantify the damage due to this umbrella pricing to a total of about 7.34 million euros'. These data may be an important tool for consumer associations to use 'in order to claim damages before national courts and thereby actively fulfil their mandate of consumer protection'.

7 Cartels are not only detrimental for consumers; they can also have an adverse impact on growth. Petit \& Kemp \& J van Sinderen, 2015, p. 501, use cartel and industry data on productivity growth to estimate the impact of cartel formation, cartel presence, and cartel termination on the total productivity growth in the Netherlands between 1982 and 1998. They conclude that their 'research results suggest that cartel presence, indicated by registration status in the cartel register, indeed curbs productivity growth'. 
loss is too small to motivate them to litigate (Guiné, 2014, p. 225). Popular action (actio popularis) efficiently solves another problem, which concerns the standing to sue, 'when the interests harmed by the anticompetitive practises are not related to a specific case.' The problem is solved by 'freeing the private individuals from the need to demonstrate infringement of an individual right' (Correia, 2010).

\section{Factors which ground the recommendation's hostility to the opt-out models}

\section{A. The White Paper's suggestion on the opt-in model}

The Directive on private enforcement does not require Member States to introduce class actions or any other type of collective redress. ${ }^{8}$ The European Commission addressed the collective redress topic through a soft law instrument.

In April 2008, the European Commission launched a White Paper for public consultation on damages actions for breach of EU antitrust rules. ${ }^{9}$ It proposed that EU legislation should implement an 'opt-in' collective action. ${ }^{10}$

'The opt-out model has been the subject of considerable attention during the public consultation held by the Commission on the topic of a coherent approach to collective redress. As explained by Judge Jones in his contribution to the public hearing on collective redress held by the Commission on 5 April 2011, the opt-out system presents undeniable advantages and must be examined, not from the perspective of American class action litigation, but from the perspective of European experience, with a view to devising a European mechanism for collective redress that will ensure access to justice and compensation, but which will present acceptable safeguards to prevent the excesses that have repeatedly been attributed to the US model' (Delatre, 2011, p. 29).

8 Piszcz, 2017, addresses the different legal solutions adopted by Central and Eastern Countries on compensatory collective redress.

9 White Paper on Damages Actions for Breach of the EC antitrust rules COM(2008) 165, 2.4.2008 Available at http://eur-lex.europa.eu/legal-content/EN/TXT/PDF/?uri=CELEX:5200 8DC0165\&from $=$ EN (accessed November 2017).

10 The White Paper, p. 4, proposes 'opt-in collective actions, in which victims expressly decide to combine their individual claims for harm they suffered into one single action'. 
The White Paper does not give reasons for preferring the opt-in model. However, the Staff Working Paper ${ }^{11}$ briefly addresses the issue, weighing the pros and cons of the opt-in versus opt-out solution. It explains that: 'An opt-in collective action system would usually result in a smaller number of victims claiming damages than in an opt-out system, thereby limiting corrective justice, and would have as a consequence that some of the illicit gain may be retained by the infringers, thereby limiting the deterrent effect of the mechanism. By requiring the identification of the claimants (and the specification of their alleged harm suffered), an opt-in collective action may also render the litigation in some way more complex since it increases the defendant(s) possibility to dispute each victim's harm. However, the analysis in the field of competition suggests that an opt-in collective action should be preferred to an opt-out collective action in which a person can bring an action on behalf of a class of unidentified persons. Combined with other features, such opt-out actions have in other jurisdictions been perceived to lead to excesses. There is an increased risk that the claimants lose control of the proceedings and that the agent seeks his own interest in pursuing the claim (principal/agent problem). Opt-in mechanisms are more similar to traditional litigation and would therefore be more easily implemented at national level.'

The objective set out in the White Paper was to ensure that 'all victims of infringements of EU competition law have access to effective redress mechanisms so that they can be fully compensated for the harm they suffered.' However, a question arises: given that objective, is the opt-in group action the best way to achieve it? Some authors argue that 'the compensation of all victims of EU competition law infringement is impossible. The concern is therefore to ensure that as many victims as possible will be compensated for the harm they suffered. In this context, the choice of which type of procedure should be developed - opt-in or opt-out - is fundamental' (Delatre, 2011, p. 36).

\section{B. The Recommendation on Collective Redress and the rejection of the opt-out model}

In 2013, the Commission adopted the Recommendation on Collective Redress $^{12}$, its principles are intended to apply to claims regarding rights granted

11 Commission, 'Commission Staff Working Paper accompanying the White Paper on Damages Actions for Breach of EC Antitrust Rules' COM (2008) (Staff Working Paper) 165 final.

12 Commission Recommendation of 11 June 2013 on common principles for injunctive and compensatory collective redress mechanisms in the Member States concerning violations of rights granted under Union Law (2013/396/EU). 
under EU law in a variety of areas, including competition law. ${ }^{13}$ Some previous initiatives (including some surveys) developed by the European Commission had shown the variety of national legal solutions for collective redress. In possession of this information, the European Commission chose to tackle the collective redress issues by enacting a soft law instrument. ${ }^{14}$

It is not the purpose of the Recommendations to harmonise national legal regimes. ${ }^{15}$ This means that national legal variations on collective redress experiences will remain, in spite of the common principles for injunctive and compensatory collective redress mechanisms set out in the Recommendation.

The European Commission thus identified the main principles to be adopted by the national laws of each Member State, but tolerates the current range of national legal solutions. In fact, the Recommendation is not, by nature, a mandatory instrument, and, consequently, it has the advantage of showing the path to be followed without imposing immediate national legal reforms. By doing so, the European Commission rejects the 'one size fits all' approach.

Collective redress instruments are an important tool to encourage and enhance private enforcement of competition law in Europe (Peyer, 2012, p. 351). The Recommendation finds that competition is an area "where the supplementary private enforcement of rights granted under Union law in the form of collective redress is of value'. ${ }^{16}$

The aim of the Recommendation 'is to facilitate access to justice in relation to violations of rights under Union law and to that end to recommend that all Member States should have collective redress systems at national level that

13 In April 2008, the European Commission published for public consultation a White Paper on damages actions for breach of EU anti-trust rules. All the Commission initiatives on collective redress can be found at http://ec.europa.eu/consumers/solving_consumer_disputes/ judicial_redress/index_en.htm. On 22 May 2017, the Commission launched the public consultation 'Call for evidence on the operation of collective redress arrangements in the Member States of the European Union'. 'The European Commission is assessing how the Commission Recommendation of 11 June 2013 on common principles for injunctive and compensatory collective redress mechanisms in the Member States concerning violations of rights granted under Union Law is being implemented in practice.' The consultation took place between 22 May 2017 to 15 August 2017 (12 weeks).

14 According to Article 288 of the Treaty on Functioning of the European Union, the 'Recommendations and opinions shall have no binding force'.

15 Hodges \& Voet, 2017, find that 'There is no coherence in national class action laws, none of which correspond to the European Commission's 2013 blueprint'. Buccirossi \& Carpagnan, 2013 , p. 3, suggest that 'a legislative intervention on collective redress in antitrust at EU level may be needed to improve the effectiveness of the private enforcement of EU competition law. This intervention could have article 103 TFEU as legal basis and the most effective legislative act would be a regulation.'

16 Recital 7 of the Recommendation. 
follow the same basic principles throughout the Union, taking into account the legal traditions of the Member States and safeguarding against abuse'. ${ }^{17}$

According to the European Commission Recommendation, the principal aim and purpose of this soft law act is to 'stop illegal practices and enable injured parties to obtain compensation in mass harm situations caused by violations of rights granted under Union law, while ensuring appropriate procedural safeguards to avoid abusive litigation' ${ }^{18}$ However, it is a controversial issue among authors whether or not the current US class action legal regime incorporates the right procedural safeguards to ensure that only reasonable, well-grounded actions are allowed to proceed. Furthermore, it is important to consider whether the peculiarities of national traditions in Europe, the "path dependence', contribute to the same kind of abuses that are allegedly practised by the US legal industry.

The European Commission consistently puts forward a number of 'principles common to injunctive and compensatory collective redress' that are designed to be followed by national legal regimes on collective redress. These principles cover a wide range of legal aspects: $a$ ) standing to bring a representative action; $b$ ) admissibility; $c$ ) information on a collective redress action; $d$ ) reimbursement of legal costs of the winning party; $e$ ) funding; $f$ ) cross-border cases. Then the European Commission identifies 'specific principles relating to injunctive collective redress'.

For the purposes of this paper, it is relevant to consider the 'specific principles relating to compensatory collective redress', ${ }^{19}$ in particular the recommendation concerning the 'constitution of the claimant party by the 'opt-in' principle'. ${ }^{20}$ The Recommendation suggests that the 'claimant party should be formed on the basis of express consent of the natural or legal persons claiming to have been harmed ('opt-in' principle). Any exception to this principle, by law or by court order, should be duly justified by reasons of sound administration of justice'. ${ }^{21}$ This option is contrary to Rule 23 of the US Federal Rules of Civil Procedure, which adopts the opt-out model.

The Recommendation looked at the US class action regime and experiences and, as result, very clearly one of the Recommendation's main purposes is to avoid certain alleged abuses, especially those consistent with unmeritorious litigation. 'There is a widely held belief among corporate and government stakeholders that the US class actions regime is not the right fit for Europe'. (Geradin, 2015, p. 9).

\footnotetext{
17 Recital 10 of the Recommendation.

18 Recommendation, Recital 1.

19 Recommendation, no. 19-20.

${ }^{20}$ Recommendation, no. 21.

21 Recommendation $n \stackrel{n}{0} .21$.
} 
Whether the US class action regime favours 'strike suits' or not is beyond the scope of this paper. In fact, this class action regime is controversial both within and outside the United States. It has several advantages and, at the same time, is open to several criticisms. The advantages of class actions (including competition class actions) are: $a$ ) they overcome the economic barrier faced by individual claimants whose claim is too small to fund the litigation against the defendant; $b$ ) they aggregate a large number of individual claims, which concentrates the litigation and therefore saves time, energy and resources of the defendant; $c$ ) they induce a deterrent effect through the award of treble damages.

However, the risks of class actions are well known. Critics point out that the legal industry has developed practices to secure a settlement regardless of the merit of the claim. In fact, some risk-averse defendants (who want to avoid reputational damage) prefer to pay a settlement instead of going to trial and succeeding. Another critic points out that a sole claimant receives minimal compensation. In short, according to this critic, class actions generate benefits and profits for the lawyers, rather than for the injured consumers.

The Recommendation is very cautious, even conservative, with respect to the US experiences with class actions. In keeping with this approach, the Recommendation states that 'elements such as punitive damages, intrusive pre-trial discovery procedures and jury awards, most of which are foreign to the legal traditions of most Member States, should be avoided as a general rule'. ${ }^{22}$ Some authors detect a 'clear hostility towards the US class actions regime, which is perceived as a source of excessive litigation and unmeritorious claims' (Geradin, 2015, p. 13).

The Recommendation acknowledges that collective redress mechanisms are crucial to achieving an effective private enforcement of competition law and perhaps the European regulator recognizes that the US class action regime promotes such effectiveness. Understandably, it is neither possible nor desirable to advocate a complete and blind 'legal transplant' (Watson, 1993) of the US class action system to the European legal regime. Nor should it be forgotten that a number of factors have contributed to the current US class action legal regime (economic, social, legal environmental, litigation culture). It is to be expected that such an attempt at a 'legal transplant' would not succeed. The European Commission is aware of the problems caused by the legal transplant or 'legal borrowing' (Fleischer, 2005). Of course, tolerating class action abuses would be neither desirable nor help to cultivate efficiency. There is no doubt that the misuse of class action lawsuits must not be tolerated under European regulations.

22 Recital 15 of the Recommendation. 
The Recommendation rejects the contingency fee arrangement for paying the lawyer and other economic incentives which can lead to excesses and abuses, such as punitive damages.

Delatre points out that 'That opt-out mechanisms, by themselves, engender litigation excesses is usually considered a given, and rarely grounded by empirical evidence, other than a vague reference to the US class action' (Delatre, 2011, p. 20-21). This Author, analysing the European Commission's hostility towards the opt-out model, points out that 'The only document which considers the opt-in/opt-out debate is the impact study. It covers the topic in three pages of what can arguably be regarded as a shopping list of issues and concerns, shows a complete lack of empirical data and provides no analysis of any kind' (Gaudet, 2008, p. 107-108).

This lack of empirical data grounding the opt-out model could weaken the statements of the European Commission rejecting the opt-out model. In fact, it is crucial to be aware of the opt-out risks and simultaneously assess whether or not the European legal regimes favour such risks. It is important to understand why risks arise, the economically, socially and culturally driven forces which lead to the alleged litigation abuse culture in the US. Does the European legal and cultural environment trigger the same risks, incorporate the necessary safeguards? These are relevant issues to be addressed.

\section{Assessing the Recommendation on Collective Redress proposals}

Most recently, the European Commission evaluated the impact of the 2013 Recommendation, assessing whether further EU action is needed. In this context, the European Commission launched a 12-week Public Consultation running from 22 May 2017 to 15 August 2017.23 This consultation aimed 'to collect information on stakeholders' practical experiences with collective actions, both injunctive and compensatory as well as on situations, where collective action could have been appropriate, but was not sought'.

Additionally, "the U.S. Chamber Institute for Legal Reform (ILR) has commissioned a survey of the "state of play" in 10 Member States (including all of the largest economies) and covering 16 separate collective redress mechanisms'. ${ }^{24}$ This survey addresses the 'litigation abuse' issues. Consequently, 'it contains a particular emphasis on where collective redress

${ }^{23}$ For further information see 'Call for evidence on the operation of collective redress arrangements in the Member States of the European Union', available at http:/ec.europa. eu/newsroom/just/item-detail.cfm?item_id=59539,: Deadline: 15 August 2017 (Accessed November 2017).

${ }^{24}$ U.S. Chamber Institute for Legal Reform, 2017: 2. 
mechanisms might be vulnerable to abuse, and on safeguards to mitigate against these abuses'. ${ }^{25}$ This survey concludes that the opt-out model may contribute to unmeritorious litigation, especially when the third party litigation funding drives the "possibility of claims inspired mainly by entrepreneurial lawyering or "investors" in litigation being greatly swollen, so that the value of their potential winnings will also swell. Experience has shown that the main beneficiaries in such scenarios are typically the lawyers, with consumers often getting nothing of value'. ${ }^{26}$

This survey expresses deep concerns about the risks of the opt-out models, especially when collective redress is captured by hedge funds or private equity interests. In such situations, the litigation costs through 'third party funding' can induce opportunistic claims filed to serve the funders' interests rather than to compensate consumers. 'Increasingly, financial investors (often private equity or hedge funds) are identifying, organising, instigating and managing cases by marketing to victims and then hiring and paying lawyers, all in exchange for a significant percentage of the recovery'. ${ }^{27}$ The survey therefore suggests some third-party litigation funding safeguards, such as 'Implementing Licensing Through a Government Agency'. ${ }^{28}$

Even though the survey highlights the risks arising from the opt-out model, Portugal and the Portuguese opt-out experience lie outside the survey's scope. The question (not answered by this survey) is whether the Portuguese opt-out model facilitates the opportunistic claims risk.

\section{D. 'A New Deal for Consumers' and the representative action}

Recently (April 2018) the Commission presented a proposal titled 'A new deal for consumers', which aims to strengthen consumer rights and to improve enforcement tools. Regarding consumer rights' enforcement, the Commission rejects (once again) the US-style class actions. According to the Commission, the representative model is the best way to enforce consumer rights and is the 'European way'. The European Commission wants to avoid unmeritorious claims (according to the Commission, one of the major risks of the US-style model). The representative action will be open to non-profit consumer organizations who act 'on behalf of a group of consumers that have been harmed by an illegal commercial practice'. According to the European Commission draft 'New Deal for Consumers', representative actions will not

\footnotetext{
25 U.S. Chamber Institute for Legal Reform,2017: 2.

26 U.S. Chamber Institute for Legal Reform,2017: 4.

27 U.S. Chamber Institute for Legal Reform, 2017: 29.

28 U.S. Chamber Institute for Legal Reform, 2017: 5.
} 
be open to legal firms. The European Commission suggests that law firms are reward driven organizations, which can induce the unmeritorious litigation risk. It is not clear why the representative model, as it is presented by the European Commission, avoids the unmeritorious litigation risk.

The 'New Deal for Consumers' proposal is wider than the private enforcement of competition law, but when implemented, it can have impact on this field. According to the European Commission, representative actions are the future of consumer rights enforcement in the European Union. Once again, the European Commission refuses US-style class actions and rejects opt-out collective redress. However, it is important to stress that US-style class actions have influenced some European legal systems in the field of private enforcement of competition law and the opt-out model constitutes a part of some European countries' legal experiences, including Portugal.

\section{Challenging the European Commission - the spread of opt-out models in Europe}

\section{A. The opt-out model makes part of the European legal experience}

It is expected that the Recommendation will trigger some legal reforms within the European national legislation on collective redress, mainly in the field of private enforcement of competition law.

However, the legal reforms endorsed by this Recommendation depend on a political choice or political decision. Of course, the recommendation aspires to be a driving force for bringing the national rules on collective redress closer together. According to the draft Recommendation, harmonization or legislative approximation will be achieved not through mandatory directives but by soft law that suggests the principles that might be adopted by each national jurisdiction.

Given that the Recommendation is a soft law instrument, it is appropriate that each Member State makes a legal assessment of the effectiveness of the Recommendation's provisions. In spite of the European Commission rejecting the opt-out model, fact is that it is part of the European experience and tradition. According to the U.S. Chamber Institute for Legal Reform survey's findings, 'the following are opt-out or hybrid mechanisms: Belgium (Collective Redress Actions), Bulgaria (Proceedings in Collective Actions), Germany (KapMuG), Netherlands (WCAM), Spain (Collective Actions), the UK (CAT) and the UK (Representative Proceedings). Except for the Spanish system, these opt-out or hybrid systems have all been introduced 
since 2005, which could indicate a possible shift away from opt-in systems in recent years. ${ }^{29}$

Gaudet points out that Swedish, Norwegian, Danish, and Dutch experiences contradict several reasons given in the Commission's White Paper for favouring opt-in over opt-out class actions. Lacking persuasive reasons to reject Europe's most powerful mechanism, the Commission should take a hard look at opt-out class actions (Gaudet, 2008, p. 107).

Portugal has adopted the opt-out model consistently since 1995. Pursuant to Article 15 of the LAP (Law of Actio Popularis), the claimant party is formed based on the non-exclusion of persons who have been harmed. Under Belgian law, it is for the judge to decide whether an action can be based on an opt-in or opt-out model. This legal possibility does not exist in Portuguese law. The judge has no authority to choose the model on which the actio popularis is based.

Under the British Consumer Rights Act 2015 (Bass \& Henderson, 2015, p. 716), the Competition Appeal Tribunal must state in the collective proceedings order whether the collective proceedings are opt-in or opt-out. Consequently, the Competition Appeal Tribunal has the power authority to decide that the proceedings will follow the opt-out model, which is more appropriate in situations involving many consumers with small claims. ${ }^{30}$

\section{B. The opt-out model - advantages, incentives and risks}

There is a basic consensus that the opt-out model remains controversial, despite its implementation in several European legal systems. Literature intensively explores its merits, risks and shortcomings.

Legal and economic literature identifies the main risks of the opt-out model (Delatre, 2011, p. 44). Summing up such risks:

a) The opt-out action is expensive. This objection stems from the USA experience where lawyers' contingency fees, the cost of certification and the cost of distributing the compensation increase litigation costs.

$b$ ) The opt-out model implies the principal-agent problem. This criticism focuses on the risk that rather than the represented group, the settlements negotiated by the plaintiffs mainly benefit their own interests. According to this criticism, the represented consumers do not have effective resources to monitor the conduct of the lead plaintiff or the lawyers and this situation could trigger a conflict of interests.

29 U.S. Chamber Institute for Legal Reform, 2017: 38.

${ }^{30}$ See Section 47 (B) 2 and Section 47(B)(4). 
c) The opt-out model does not grant the right to a 'day in court', meaning that consumers are not granted procedural rights. Consumers who do not opt-out are bound by decisions they have not expressly consented to, because the opt-out model only requires passive consent.

d) The opt-out model favours or triggers unmeritorious litigation. This objection stems directly from the USA experience with class actions, where some legal and cultural factors favour unmeritorious or frivolous litigations aimed to force the defendant to settle the action. Yet, it is relevant to understand whether unmeritorious litigations are an opt-out outcome or, on the contrary, whether they stems from a convergence of legal, historical and cultural factors.

The claimant's passive/active consent is a critical issue in competition collective redress actions. 'In the opt-in mechanism, the potential victim of an infringement is expected to actively join and potentially participate in the action, but is allowed not to, which implies remaining passive. This is called active-consent. It will require at least some, if not considerable, effort on the victim's part. The victim will therefore have to surmount several obstacles every step of the way, one of which is simply his or her own reluctance to participate in something as serious as a lawsuit. In the opt-out model, the potential victim is automatically opted-in, and is expected to remain passive - although nothing forbids him or her from taking a more active role in the action - but is authorised to expressly opt-out. This is called passive consent. In the former, action allows one to join the procedure, whereas in the latter, inaction allows one to remain part of the procedure' (Delatre, 2011, p. 45).

In the context of small claims, private enforcement of competition law faces the issue of rational consumer apathy, which guides towards an under-enforcement of the right to be compensated for the damage arising from the breach of competition law. In such a context, the opt-out model may contribute: $a$ ) to potentially better serve corrective justice; $b$ ) to override 'consumer apathy'; $c$ ) to increase the rate of participation in competition collective redress actions.

On the other hand, the opt-in model: $a$ ) is a deterrent against unmeritorious lawsuits; $b$ ) promotes meritorious claims; $c$ ) encourages defendants to contest unmeritorious claims; $d$ ) grants procedural rights to claimants and; $e$ ) is an expression of the active consent of the claimant.

Literature suggests that the opt-in model is deterring meritorious claims and complainants. 'In this particular context, the opt-in class action ceases to be neutral and actually becomes a deterrent rather than an incentive' (Delatre, 2011, p. 46). Empirical data show the low participation rates achieved by the opt-in models. In fact, statistics demonstrate that a relevant number of victims do not opt-out, but an overwhelming majority of potential victims tend not to 
opt-in (Delatre, 2011, p. 48). Mulheron, in her survey of the opt-in group and representative actions in Europe, finds that, overall, the rate of participation in opt-in actions is on average lower than 1\% (Mulheron, 2008, p. 154).

These data are especially important when we consider that small claims are sensitive to consumer rational apathy effects and, therefore, when there is little economic incentive to bring the cartelists to the court.

\section{Rewards and safeguards of the Portuguese opt-out collective redress action}

\section{A. Competition law infringements and compensation of the injured consumers}

It must be recognized that a wide range of factors can contribute to the effectiveness or ineffectiveness of a concrete collective redress legal regime. This is a very complex balance because, on one hand, there are efficiency requirements and, on the other, there are individual rights, particularly procedural rights. The assessment of this balance varies according to the legal choice on collective redress made by each of the legal regimes.

Article 52(3) of the Constitution of the Portuguese Republic, entitled 'Right to petition and right of actio popularis', states that 'Everyone is granted the right of actio popularis, including the right to apply for the applicable compensation for an injured party or parties, in the cases and under the terms provided for by law, either personally or via associations that purport to defend the interests in question. The said right may particularly be exercised in order to: a) Promote the prevention, cessation or judicial prosecution of offences against public health, consumer rights, the quality of life or the preservation of the environment and the cultural heritage; b) Safeguard the property of the state, the autonomous regions and local authorities'.

These constitutional provisions must be substantiated by ordinary law. At the level of ordinary law, the actio popularis is regulated by Law no 83/95 of 31 August (hereinafter; LAP) ${ }^{31}$ It precedes the European Commission Recommendation on collective redress since it was published on 31 August 1995 and came into force 60 days afterwards (Machete, 1996, 269). Concerning the areas covered by collective redress (scope of application), Article 1(2) LAP states that the interests protected by actio popularis are public health, environment, quality of life, consumer rights, cultural heritage, and public domain.

31 This law has been amended by Decree-Law No 214-G/2015 of 2 October. 
Under Portuguese Law, a popular action may not be used indiscriminately, but only to protect meta-individual interests materially qualified by the Constitution or the law. The actio popularis endeavours to protect diffuse interests and collective interests, defined as 'supra-individual' (that is, above the individual), together with homogeneous individuals (that is, fragmented) interests or rights.

Competition is not expressly included in the list of the interests covered by the actio popularis. Furthermore, the Portuguese Competition Law (Law no 19/2012, 8 May) does not provide for collective redress mechanisms. In spite of this legal silence, one must argue that the Portuguese legal regime on action popularis can also be used to seek compensation for damages arising from infringements of competition law, at least when consumer protection is at stake (Abreu, 2011, p. 108).

The Portuguese legal regime allows the private enforcement of competition law through the compensatory actio popularis. The legal grounds that sustain this position are: $a$ ) references in the Portuguese Constitution and in Article 1(2) LAP are not exhaustive (Rossi \& Ferro, 2013, p. 49-50); b) the Supreme Court confirmed this point of view; $c$ ) Article 1(2) LAP clarifies the meaning of the expression 'consumer rights' used in Article 52(3) of the Constitution of the Portuguese Republic 'when defence of popular action is admitted in order to prevent, terminate and legally prosecute infringements of the "protection of the consumption of goods and services"' (Correia, 2010, p. 112).

The Preliminary draft proposal for a law transposing the private enforcement directive, ${ }^{32}$ presented by the Autoridade da Concorrência, clarifies this question. Article 19(1) of the Preliminary Draft proposal states that 'Actions for damages as a result of infringements of competition law may be brought under Law No 83/95 of 31 August, as amended by Decree-Law No 214-G/2015 of 2 October, and the following paragraphs also apply to them'.

Given the particularities of the actio popularis, the LAP establishes special rules of legal standing to sue. According to the LAP, any natural person is entitled to legal standing to sue provided they are in full enjoyment of their civil and political rights. Under the Portuguese legal regime on actio popularis, a company (such as a SME) that is a client or consumer of the undertaking responsible for the competition infringement may not file an actio popularis as the lead plaintiff.

The actio popularis may be filed by associations and foundations whose articles of association focus on the promotion of interests recognized by

32 http://concorrencia.pt/vPT/Noticias_Eventos/ConsultasPublicas/Paginas/Consulta_ Publica_PrivateEnforcement.aspx. For a critical examination of the Autoridade da Concorrência Preliminary Draft, see Costeira, 2017, p. 175, ff. 
Article 1 LAP, regardless their direct interest in the outcome of the action (Article 2(1) LAP). It seems that neither Article 52(3) of the Constitution nor Article 2(1) LAP 'impose any requirement of material connection between the citizen that initiates the action and the infringement in question (meaning, e.g., that a citizen need not have personally suffered damage as a result of the antitrust infringement in order to have standing to initiate an actio popularis' (Rossi \& Ferro, 2013, p. 50).

According to Article 19(2) of the Preliminary Draft, the standing to bring actions for damages as a result of infringements of competition law under Law no 83/95 of 31 August is recognized in 'Associations and foundations whose aim is consumer protection' and 'Associations of undertakings whose associates are injured by the infringement of competition law in question, even if their statutory object does not include the protection of the competitive process'.

Legal standing to sue is also granted to local authorities, which can seek compensation for the injured persons living within the territorial boundaries of the local authority (Article 2(2) LAP). Finally, legal standing to sue is recognized in the Public Prosecution Service ${ }^{33}$ (Article 16 LAP). ${ }^{34}$

The Portuguese legal system does not have a requirement regarding either the 'numerosity' of the members or the 'adequacy of representation' (a requirement that the persons who represent the group of claimants will fairly and adequately protect the interests of the class) (Martins, 1996, p. 112).

Furthermore, according to Article 14 LAP, the plaintiffs, on their own initiative, without the need for a mandate or express authorization, represents all the other holders of the right or interests in question who do not opt-out. Consequently, according to the Portuguese legal regime, the association, the consumer or the client who files the actio popularis against the defendant (company) will represent all the consumers/clients who suffered damage because of that infringement and did not opt-out.

\section{B. The Portuguese opt-out model - rewards and risks}

From the several European legal experiences on opt-out collective redress actions, one may conclude that there are differences which identify each of

33 According to Article 219(1), of the Constitution of the Portuguese Republic, 'the Public Prosecutors' Office has the competence to represent the state and defend the interests laid down by law, and, subject to the provisions of the following paragraph and as laid down by law, to participate in the implementation of the criminal policy defined by the entities that exercise sovereignty, exercise penal action in accordance with the principle of legality, and defend democratic legality'.

34 See also Article 31 of the CPC. 
the experiences. Consequently, it is important to analyse the Portuguese optout model to assess the risks arising from it and the rewards provided by it.

Article 15 LAP sets forth the consumer's right to opt-out. Article 19 of the 'Preliminary draft proposal for a law transposing the private enforcement directive'35, presented by the Autoridade da Concorrência, addresses 'collective redress', but it does not accept the European Commission Recommendation on implementing the opt-in model. The Portuguese legal system continues to follow an opt-out model, in spite of the opt-in based Commission Recommendation.

To enable them to opt-out, potential claimants are informed about the filing of actio popularis through announcements published in social media or through public notices (Article 15(2)(3) LAP). ${ }^{36}$ These publications serve the interest of each claimant by letting them decide whether they want to exercise the right of self-exclusion or not. This decision must be taken within the deadline fixed by the judge, within the period fixed for the presentation of evidence or within a similar stage in the proceedings.

A decision not to opt-out is assumed to equal the acceptance of the proceedings. In mass harm situations, it may be admitted that the actio popularis will cover consumers or clients who are not aware of their right to full compensation for the loss, because: $a$ ) the announcements will not identify all the injured parties; $b$ ) the consumer is not aware of the loss; $c$ ) the consumer has no access to the announcements. In all these situations, the consumer or client will be part of the group represented by the applicant.

'One of the main criticisms of the opt-out mechanism is its alleged cost' (Delatre, 2011, p. 49). Under this perspective, the opt-out model makes the collective redress expensive, considering lawyers' contingency fees, the costs of the certification and the costs of distributing the compensation. ${ }^{37}$

Some of these costs (typical in the USA opt-out experience) do not exist under the LAP, because it does not provide for a preliminary certification mechanism regarding the entitlement to take action, nor does the Portuguese legal system allow lawyers' contingency fees. Additionally, the LAP provides for an inexpensive regime for court costs (Article 20). ${ }^{38}$

35 http://concorrencia.pt/vPT/Noticias_Eventos/ConsultasPublicas/Paginas/Consulta_ Publica_PrivateEnforcement.aspx. For a critic examination of the Autoridade da Concorrência Preliminary draft, see Maria José Costeira, supra note 90 at 175-184.

36 Gouveia \& Garoupa, 2012, point out that 'poster or press may not be the best way to notify potentially interested parties when those interests might be diffused (especially for well-defined homogeneous groups of individuals).'

37 See White Paper Impact Study, n. 16, 570.

38 According to the European Commission White Paper on Damages actions for breach of the EC antitrust rules, Brussels, 2 April 2008 COM (2008) 165 final, 'Member States could also 
Another opt-out model risk is related to the 'Principal-agent Problem', considering that the represented consumers do not have effective resources to monitor the conduct of the lead plaintiff or the lawyers, and this situation could trigger a conflict of interests. The LAP thus endows the court and the Public Prosecution Service with the authority to be the 'gatekeeper' of the sound development of the actio popularis (Articles 13, 16 LAP).

It is alleged that the opt-out model does not grant the 'right to a day in court', saying that this model of collective redress does not grant the procedural rights of consumers. In fact, consumers who do not opt-out are bound by the res judicata (Article 19 LAP). Under Portuguese Law, plaintiffs are only allowed to opt-out up until the end of the production of evidence stage. Additionally, Portuguese legislation does not recognize the right to optout from the settlement. Under other regimes, the plaintiffs may opt-out of the settlement. ${ }^{39}$

It is common knowledge that the opt-out model favours or triggers unmeritorious litigation, forcing the defendant to settle frivolous actions (the so-called 'blackmail settlements'). The Portuguese legal experience shows an under-enforcement of the consumer right to be compensated for loss caused by competition law breaches. In fact, the Autoridade da Concorrência has detected and punished several cartels. However, this outcome of the Autoridade's activity did not facilitate the flow of collective follow-on actions.

The Portuguese legal experience is internationally mentioned as providing an incentive to get very high participation rates. In fact, Mulheron's study on the Portuguese experience (none of the cases studied were related to competition law infringements) estimates the rate of participation in opt-out class actions in Portugal to be close to $100 \%$, considering the low number of victims who opt-out. Delatre finds the Portuguese legislation on actio popularis 'far reaching' and 'the closest equivalent in Europe to the US class action' (Delatre, 2011, p. 37). Hodges qualifies the Portuguese legal regime as 'the most liberal in Europe'.

In the Portuguese experience, as far as I know, there is only one case still pending where the plaintiff is claiming compensation for damage caused by competition infringements (Ferro, 2015, p. 1; Pais, 2016, p. 191). On 12 March 2015, the Portuguese Competition Observatory (a non-profit organization) filed a mass damages claim against Sport TV seeking to compensate over 600000 clients for damage caused by restrictive practices. Under this actio popularis, the Portuguese Competition Observatory sought compensation for the damage caused to consumers who were excluded from access to the

consider introducing, where appropriate, limits on the level of court fees applicable to antitrust damages actions'.

39 Article 7:908(2) of the Dutch Civil Code. 
premium channel due to the price increase induced by a restrictive practice. The suit was filed on behalf of all consumers. However, it also sought to compensate the pay-television service consumers who were affected by reduced competition between 2005 and 2013 (Ferro, 2015, p. 1, 2016, p. 140).

In the Portuguese experience, on 27 May 2015, Cogeco Cable filed an action against Sport TV and its shareholders (NOS and Controlinveste), seeking compensation caused by the competition law infringement committed by Sport $\mathrm{TV}^{40}$. In the context of this action, last November 2017, the Lisbon Court of First Instance ('Tribunal Judicial da Comarca de Lisboa') lodged a request for a preliminary ruling to the Court of Justice (hereinafter; CJEU). The Portuguese Court referred six questions to the CJEU, mainly related to the possibility of invoking Articles 9(1) and 10(2), (3) and (4) of the Directive before the former, although the transposition period had not expired yet by the time the lawsuit was brought forward ${ }^{41}$. The questions referred by the Portuguese court are related to the horizontal direct effect of directives, the obligation of interpreting national law in conformity with EU law and the principle of procedural autonomy of the Member States, the principles of equivalence and effectiveness. It is the first time, the CJEU is been asked to give a ruling on Directive 2014/104/EU. This case can be a landmark. However, it is important to stress that none of the questions referred by the national court are related to collective redress. The case is still pending.

Considering the Portuguese experience on compensatory collective redress, one could conclude that it is not sufficiently powerful to trigger collective redress for competition claims.

\section{Compensation distribution and claimant's representative reward - new approaches}

Correia points out that the opting-out model and the compensation fixed on an overall basis represent two important factors for the effectiveness of the Portuguese legal regime. 'The possibility of fixing the compensation on an overall basis means that the perpetrators can be prevented from gaining advantage from the damage even when it is not possible to establish the exact extent of the individual damage suffered' (Correia, 2010, p. 112).

40 Request for a preliminary ruling from the Tribunal Judicial da Comarca de Lisboa (Portugal) lodged on 15 November 2017 - Cogeco Communications Inc v Sport TV Portugal and Others, (Case C-637/17). Official Journal of the European Union, C 32/14, 29.1.2018.

41 At the national level, the Law n.. 23/2018, 5 June 2018, transposes Directive 2014/104/ EU into the Portuguese legal system. 
The LAP provides for the fact that, in a popular action, compensation may be awarded not only to individually identified interests but also to those that are not individually identified (Dias, 1999, p. 58). Typically, in the case of competition collective redress procedures, only some injured parties are individually identified during the proceedings, or perhaps none of them are identified at all. As Rossi and Sousa Ferro point out, 'in a great number of cases, it will simply not be rational to even attempt to take the option of individual identification of injured cases' (Rossi \& Ferro, 2013, p. 56).

According to Article 22(3) LAP, 'the holders of interests who are identified are entitled to the corresponding compensation in accordance with the general rules of civil liability' and Article 22(2) LAP states that 'compensation for a violation of the interests of parties who are not individually identified is set globally'. The interpretation of these provisions is disputed in Portuguese legal literature (Rossi \& Ferro, 2013, p. 57). The cases where an overall compensation sum may be awarded are also disputed (Rossi \& Ferro, 2013, p. 57). This legal solution should be clarified for the sake of legal certainty.

The Portuguese LAP does not specify which authorities or entities are entitled to distribute the compensation to the injured consumers. This is a major issue. In cases where the court fixes an overall sum of compensation, it is crucial to identify the entities charged with distributing the compensation to the persons covered by res judicata.

Article 19 of the 'Preliminary draft proposal for a law transposing the private enforcement directive' clarifies the solution to this question. According to Article 19(6), 'The judgment shall identify the entity responsible for receiving, managing and paying the damages due to the injured parties not identified individually, which may be, in particular, the plaintiff or one or more of the injured parties identified in the action'. The Preliminary Draft does not clarify whether the entity or person who manages the compensation distribution will be rewarded, nor does it specify who will pay for the distribution of the awarded compensation. Assuming that the injured consumers will pay for this distribution service, one may wonder whether the compensation awarded by the court may be allocated to such payment.

\section{Funding the litigation costs - are new financial incentives needed?}

The Portuguese legal system follows the 'loser pays' principle, which diverges from the 'American rule'. Additionally, lawyers' contingency fees are forbidden under Portuguese law. 'Treble damages' are illegal under Portuguese competition law, since the loss is the limit of compensation that can be awarded to a consumer harmed by a competition law infringement. No less relevant is 
the fact that the Law on Actio Popularis does not allow the plaintiff's lawyer to be rewarded by the damages awarded by the court. Additionally, the Portuguese legal system does not regulate third-party funding practices. It is open to question whether such practices are accepted by Portuguese law. The topic is addressed by literature (Duarte Gorjão-Henriques, 2015, p. 573) but this practice is absent from competition law collective redress actions.

The LAP sets forth a particular and affordable regime on court fees (Article 20 LAP). However, there are other litigation costs besides court fees, such as lawyers' fees, the cost of collecting information, economic expertise, etc.

Under current Portuguese law, the compensation awarded by the court will be distributed to the injured persons in accordance with the rules provided for in the law. Unclaimed damages will be delivered to the Ministry of the Justice (Article 22(5)), not to the plaintiff or to the lawyers' plaintiff.

In an innovative way, Article 19(7) of the 'Preliminary draft proposal for a law transposing the private enforcement directive' addresses the question of litigation costs. According to this provision, 'Damages not claimed by the injured parties within a specified period are to be paid to the plaintiff in respect of all or part of the costs, court fees, legal fees or any expenses incurred by the plaintiff in connection with the proceedings'. However, on 19 October 2017, the Council of Ministers approved draft law no 101/XIII which abolishes the provision allowing the plaintiff's litigation costs to be paid from unclaimed damages.

It is very important for legislation to correctly address the critical issue of plaintiff's litigation costs. When a competition collective redress is filed, the claimants who did not opt-out will benefit from the compensation awarded by the court, even though their contribution to the proceedings was zero. In fact, these passive members of the claimant group profit from others' procedural activism. The passive claimants obtain the benefit of compensation by freeriding.

In this context, it is important that the litigation costs, particularly lawyers' fees, do not economically demotivate plaintiff activism. In these circumstances, it is important to shape an accurate and transparent legal regime which allows the collective redress plaintiff to recover litigations costs. Otherwise, the litigation costs will constitute an economic disincentive to plaintiff activism.

One may be aware that 'Litigation abuse is fundamentally driven by financial incentives, so where representatives can profit, the risk of litigation being pursued for motives other than justice is real' ${ }^{42}$. So what is needed is that the 'balance of risks and rewards is essential to a reasonable, fair system of collective redress that does not encourage abuse'. ${ }^{43}$

42 U.S. Chamber Institute for Legal Reform, 2017: 4.

43 U.S. Chamber Institute for Legal Reform, 2017: 5. 
The legal system must not tolerate unmeritorious litigation, opportunistic claims, and 'blackmail settlements'. Collective redress actions could be an important tool to obtain compensation for injured consumers. Under the Portuguese actio popularis, although the certification rules are liberal, the risk of litigation abuse is low because the rules governing the plaintiff and lawyers' reward are very strict.

\section{Conclusions}

Consistently since 1995, the Portuguese law on action popularis has applied the opt-out model, regardless of the concrete circumstances of the claim or of the claimants. Under Portuguese law, the claimant party is formed based on the opt-out model and the judge does not have the authority to decide whether the actio popularis follows the opt-in model or the opt-out model. The European Recommendation did not compel a paradigm shift in Portuguese regulation on the formation of the claimant party.

There is no single European tradition on collective redress, only several national experiences. Some of those experiences follow the opt-out model to varying degrees, even though the European Commission Recommendation favours the opt-in model for compensatory collective redress.

It is disputable which advantages does the opt-out model actually have. The article argues that opt-out models solve the crucial economic problem caused by many consumers or clients suffering a small loss because of competition law infringements. Under those circumstances, it is rational to be apathetic, because it is very likely that the cost of filing for compensatory damages will exceed the recovery obtained from the defendant. Such rational apathy of the parties injured by competition law infringements favours the wrongfully acting companies by not extracting their illegal gains from them. By not requiring the active consent of each of the claimants, the opt-out model is able to override consumer rational apathy.

Additionally, the opt-out model potentially better serves corrective justice, because it may induce the retrieval of the illegal benefits arising from the competition law infringement and, consequently, it may contribute to a more efficient allocation of resources. Additionally, the opt-out model may help increase the rate of participation in competition collective redress actions.

The opt out model has disadvantages which are well known. From the legal perspective, the main risk arises from the passive consent of consumers. The opt-out model does not require the active consent of each consumer bound by the proceedings; it is taken that not opting-out means that the consumer 
consents to the decisions taken by the lead plaintiff. This is in fact risky, because the consumer right to be compensated is managed by the lead plaintiff, even in cases where the consumer is not aware that collective redress has been filed, and therefore has no information on which to base a decision to opt-out. This risk is mitigated through effective announcements on collective redress, which disseminate accurate and transparent information to consumers potentially bound by res judicata. New information and communication technology can be a helpful tool to reach the highest number of claimants. This might help the collective redress legal regime contribute to safeguarding the procedural rights of consumers.

However, it must be stressed that litigation abuse, frivolous and unmeritorious claims, the 'excesses' alleged by the European Commission stem from specific financial incentives which reward the lead plaintiff and their lawyer. One may conclude that litigation abuse risks are not a necessary outcome of every opt-out system; rather, this risk must be assessed considering both the concrete opt-out legal regime and its rewards and safeguards. To understand this complex balance between economic incentives and safeguards it is surely important to learn from the US class actions experience, based on empirical evidence. At the same time, it is crucial to understand whether the concrete feature of a given opt-out model favours litigation abuse.

The Portuguese opt-out compensatory collective redress system does not contain financial incentives which favour abusive and unmeritorious litigation: $a$ ) punitive damages are, in general forbidden; $b$ ) 'treble damages' are illegal; c) lawyers' contingency fees are illegal; $d$ ) Portuguese law adopts the 'loser pays' principle and rejects the 'American rule'; $e$ ) the compensation awarded by the court is allocated, not to reward the lead plaintiff's lawyer, but to compensate consumers injured by the competition law infringements; $f$ ) third party litigation funding practices are absent from the competition collective redress actions.

Since 1995, the Portuguese legal experience tests the opt-out model of collective redress. In Portugal, empirical evidence shows an under-enforcement of consumer right to seek full compensation for the damage or loss caused by a competition law infringement. The Autoridade da Concorrência activity on cartel detection and punishment failed to boost follow-on compensatory actions. Additionally, to my knowledge, there are no reported cases of unmeritorious or frivolous litigation. The still pending mass damages claim filed by the Competition Observatory against Sport TV is partially a follow-on action based on the competition law infringements detected by the Autoridade da Concorrência.

The issues of litigation costs and the plaintiff's lawyer's reward are relevant to the effectiveness of collective redress. Under the LAP, it is forbidden to reward the plaintiff's lawyer from the compensation awarded by the court. 
It is fair for the plaintiff to be compensated for the expenses entailed by the proceedings. An affordable legal regime on legal costs is not enough, because passive consumers will get free-riding compensation. To compensate the plaintiff fairly and transparently for the expenses caused by the actio popularis proceeding is a crucial issue that should be granted in order to improve private enforcement of competition law.

\section{Literature}

Abreu, J.M.C. (2011). Private enforcement of competition law in Portugal, in: L. Velasco San Pedro, coord., Private enforcement of competition law, Valladolid: Lex Nova.

Alan Watson, W. (1993). Legal transplants. An approach to comparative law, 2nd edition, Georgia: University of Georgia Press.

Bainbridge, S. (2002). Corporation law and economics, Foundation Press.

Bass, A.E. and \& Kenny A. Henderson, K.A. (2015). UK: A New Dawn for Antitrust Class Actions, Journal of european competition law \& practice (6) 716-721.

Buccirossi, P. and Carpagnan, M. (2013). Is it Time for the European Union to Legislate in the Field of Collective Redress in Antitrust (and how)?, Journal of European competition law \& practice (4), 3-15.

Buxbaum (2005). German Legal Culture and the Globalization of Competition Law: A Historical Perspective on the Expansion of Private Antitrust Enforcement, Berkeley Journal of International Law, (23), 474-495.

Cooke, J.D. (2010). Administrative regulation versus private enforcement - the EU perspective, in: Abel Mateus and Teresa Moreira (edited by), Competition Law and Economics. Advances in competition policy enforcement in the EU and north America, UK/USA: Edward Elgar.

Correia, S. (2010). The effectiveness and limitations of the Portuguese system of competition law enforcement by administrative and civil procedure means, in: Abel Mateus and Teresa Moreira (edited by), Competition Law and Economics. Advances in competition policy enforcement in the EU and north America, UK/USA: Edward Elgar.

Costeira, M.J. (2017). A transposição da Diretiva Private Enforcement: perspetiva crítica, UNIO - EU Law Journal (3), 175-184.

Delatre, J. (2011). Beyond the White Paper: Rethinking the Commission's Proposal on Private Antitrust Litigation, [8], The competition law review, (8), 29-58.

Ezrachi, A. (2017). Sponge, Journal of Antitrust Enforcement, (5), 49-75.

Fleischer, H. (2005). Aktienrechtliche Legalitätspflicht und "nützlich" Pflichtverletzung von Vorstandsmitgliedern, ZIP - Zeitschrift für Wirtschaftsrecht, 141-150.

Fleischer, H. (2005). Legal transplants in European Company Law - The case of fiduciary duties, European company and financial law review, (2), 378-397.

Freitas, L. (1996). A acção popular ao serviço do ambiente, in: : lus, Special Issue, Actas do I Congresso Internacional de Direito do Ambiente da Universidade Lusíada, Porto.

Gaudet, R. (2009). Turning a Blind Eye: The Commission's Rejection of Opt-Out Class Actions Overlooks Swedish, Norwegian, Danish and Dutch Experience, European competition law review, $(30,3), 107-130$. 
Geradin, D. (2015). Collective redress for antitrust damages in the European Union: is this a reality now, George Mason University Law and Economics Research Paper Series.

Ginsburg, D.H. (2005). Comparing antitrust enforcement in the United States and Europe, Journal of competition law \& economics (1) 427-439.

Gorjão-Henriques, D. (2015). "Third party funding” ou o financiamento de litígios por terceiros em Portugal, Revista da Ordem dos Advogados, 573-624.

Gouveia and Garoupa (2012). Class actions in Portugal, in: Jürgen G. Backhaus (coord.), Alberto Cassone (coord.), Giovanni B. Ramello (coord.), The law and economics of class actions in Europe: lessons from America, Cheltenham/Southampton: Edward Elgar.

Hodges, C. and Voet, S. (2017). Delivering collective redress in markets: new technologies, The Foundation for Law, Justice and Society, in association with the Centre for SocioLegal Studies and Wolfson College, University of Oxford, 7.

Kirst, P. and Van den Bergh, R. (2016). The European directive on damages actions: a missed opportunity to reconcile compensation of victims and leniency incentives, Journal of competition law \& economics, (12), 1-30.

Laitenberger, U. and Smuda, F. (2015). Estimating consumer damages in cartel cases, [11] Journal of competition law \& economics, (11), 955-973.

Lilian T.D. Petit, L.T.D. and Kemp, R. and van Sinderen, j. (2015). Cartels and productivity growth: an empirical investigation of the impact of cartels on productivity in the Netherlands, Journal of competition law \& economics, (11), 501-525.

Loureiro, F.L. (2017). Direito penal da concorrência - a tutela da liberdade concorrencial e a criminalização do cartel, Coimbra: Almedina.

Machete, R., (1996). Acção procedimental e acção popular - Alguns dos problemas suscitados pela Lei 83/85, de 31 de agosto, in: lus, Special Issue, Actas do I Congresso Internacional de Direito do Ambiente da Universidade Lusíada, Porto.

Mariusz Maciejewski, M. (2015). Overview of existing collective redress schemes in EU Member States, Directorate General for Internal Policies. Policy Department a: economic and scientific policy, available at http://www.europarl.europa.eu/document/ activities/cont/201107/20110715ATT24242/20110715ATT24242EN.pdf (accessed on 18 June 2017).

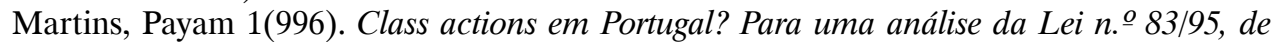
31 de agosto: Lei de participação procedimental e de acção popular, Lisboa: Cosmos.

Mateus, A. (2006). Sobre os fundamentos do direito e economia da concorrência [66] Revista da Ordem dos Advogados, (66), 1076.

Maurice E. Stucke, M.E. (2013), Is competition always good?, Journal of Antitrust Enforcement, (1), 162-197.

Michael R. Baye. M.R. and Wright, J.D. (2011). Is Antitrust Too Complicated for Generalist Judges? The Impact of Economic Complexity and Judicial Training on Appeals, The Journal of Law \& Economics, (54), 1-5.

Mulheron, Competition Law Cases under the Opt-out Regimes of Australia, Canada and Portugal (Report submitted to the Department for Business, Enterprise and Regulatory Reform, October 2008.

Notaro, G. (2014). Methods for quantifying antitrust damages: the pasta cartel in Italy, [10] Journal of competition law \& economics, (10), 87-106.

OECD Interim Report on Convergence of Competition Policies, 1994. OECD/GD (94)64, in Annex, Areas of Convergence in Competition Policy and Law. 
Orlando Vogler Guiné, O.V. (2014), A decisão de litigar, in: III Congresso Direito das Sociedades em Revista, Coimbra; Almedina.

Pais, S. (2016). "Practical Private Enforcement: Perspectives from Portugal”. In Bergström, Maria, Iacovides, Marios, Strand, Magnus (coord.), Harmonising EU Competition Litigation, The New Directive and Beyond, Swedish Studies in European Law, Volume 8, Hart Publishing, p. 187-202.

Pepper, S. (1995). Counseling at the limits of the law: an exercise in the jurisprudence and ethics of lawyering, Yale Law Journal, (104), 1545-1610.

Peyer, S. (2012). Private antitrust litigation in Germany from 2005 to 2007: empirical evidence, Journal of competition law \& economics, (8), 331-359.

Piszcz, A. (2017). Implementation of the EU damages directive in central and eastern European countries, Anna Piszcz, ed., Warsaw: University of Warsaw, Faculty of Management Press,

Porto M.L. and Vilaça, J.L. and Cunha, C. and Gorjão-Henriques, M. and Anastácio, G., (2016). Lei da concorrência anotada, 2nd ed., Coimbra: Almedina.

Posner, R. (2001). Antitrust in the New Economy, Antitrust Law Journal, (68, 3), 925-943.

Rajabiun, R. (2012). Private enforcement and judicial discretion in the evolution of antitrust in the United States, Journal of competition law \& economics (8), 187-230.

Ramos, M.E. (2016). Situação do "private enforcement" da concorrência em Portugal, Revista da Concorrência e Regulação (27-28), 27-83.

Roscoe Pound, R. (1910). Law in books and law in action, American Law Review, (44), $12-36$.

Rossi, L. and Sousa Ferro, M. (2013). The private enforcement of competition law in Portugal (II): Actio populari - facts, fictions and dreams, Revista de Concorrência e Regulação (35), 36-84.

Rossi, L. and Sousa Ferro, M. (2014). Private enforcement of competition law in Portugal. Virtues and shortcomings of the "actio popularis", in: Lapplicazione delle regole di concorrenza in Italia e nell'Unione Europea, Editorale Scientifica, 263-318.

Smuda, F. (2014). Cartel overcharges and the deterrent effect of EU competition law, Journal of Competition Law \& Economics, (10), 63-86.

Sousa Ferro, M. (2015). Collective Redress: Will Portugal Show the way?, Journal of European competition law \& practice, 299-300.

Sousa Ferro, M. (2016). Antitrust Private Enforcement in Portugal and the EU: The Tortuous Topic of Tort, Global Competition Litigation Review, (4), 140-149.

Sousa Ferro, M. (2016). Antitrust Private Enforcement in Portugal and the EU: The Tortuous Topic of Tort, Global competition litigation review, 140-150. 